\title{
THE CONCEPT OF EXTRAORDINARY CRIME IN INDONESIA LEGAL SYSTEM: IS THE CONCEPT AN EFFECTIVE CRIMINAL POLICY?
}

\author{
Vidya Prahassacitta \\ Faculty Humanity, Major Business Law, Bina Nusantara University, \\ Jl. Kemanggisan Ilir III No. 45. Kemanggisan, Palmerah, Jakarta Barat, 11480 \\ prahassacitta@gmail.com
}

\begin{abstract}
The concept of extraordinary crime was a common concept in Indonesia. Adopts from the concept of the most serious crime in Rome Statute and adjusted with the Indonesian legal system. Then it developed wider and introduced into terrorism, corruption, drug abuse offenses, and child sexual abuse in legislations and Constitutional Court verdicts. The implementation of this concept generated some consequences in drafting and formulating the legislation as part of penal policy. This leads to two legal problems; first, what was the categorization of the concept of extraordinary crime? and second, what were the consequences of the concept extraordinary crime in accordance with penal policy?. Normative law research with literature study method, This was a conducted as the response of both legal problems. Using secondary data from legislation, Constitutional Court verdicts, book and journal, this research concludes that; the concept of extraordinary crime parts of criminal policy does not have any standard for the categorization. Then, as consequences of the implementation of the concept of extraordinary crime in several penal efforts are formulating in legislations. The penalty effort is not limited to criminalization and sentencing aspects but wider and shall be in line with the strategy of crime eradication and welfare protection purposes. To reach the effectiveness of the criminal policy of the concept of extraordinary crime, the penalty effort shall be in line with criminal law principles and human right basic principles.
\end{abstract}

Keywords: extraordinary crime, legal system, criminal policy, penal policy

\section{INTRODUCTION}

The concept of extraordinary crime is common and wider concept in Indonesian legal system. The concept is used for some crimes in legislations including gross violation of human right, corruption, terrorism, and child sexual abuse offenses. Then Constitutional Court also exploits this concept for drug abuse offenses through their verdicts No. 2/PUU-V/2007 and No. 3/PUU-V/2007 dated October $30^{\text {th }}$, 2007. However, this concept does not have a legal definition, so it has widely interpretation.

Adopting from the concept of the most serious crimes of international law, then the concept is introduced and adjusted in accordance with the Indonesian legal system. The most serious of the crime is an international law concept to describe the most violent crimes in humanity, and have limited crime's classification and consequences. The crimes consider as very extraordinary and become international communities concern due to its deeply shock the conscience of humanity and grave breaches threatens the peace, security, and wellbeing of the world (Muladi, 2011). When this concept is introduced in Indonesia, some principles are modified with Indonesian criminal policy. Name of this concept then recognizes as the extraordinary crime. Then, some crimes like a gross violation of human right, corruption, terrorism, drug abuse offenses, and child sexual abuse offenses are defined as 
extraordinary crimes. Subsequently, some consequences of the implementation of the concept of extraordinary crimes are introduced an extraordinary measure for the eradication of those crimes.

Consequently, development of the concept of extraordinary crime becomes wider and deliberate debate. The debate is whether the categorization meets the threshold of the concept of extraordinary crime. Other debates are whether the consequences of the concept of extraordinary crime meet with the purpose of the criminal policy. The concept of penal policy is part of the criminal policy. G. Peter Hoefnagels has argued that criminal policy consists of two instruments, penal and non-penal. Criminal law application of a repressive nature is considered to be a penal instrument. The function of this policy is to respond to two major problems. First to answer what art is regarded as a criminal offense, and second to find out what sentence should be applied to the suspect who violates the criminal offenses. The purpose of this penal policy is not just to draft an excellent criminal legislation, but wider is for crime prevention (Arif, 2008).

The research is designed as a reference for public and law students. The major purpose of the research to the public is to criticize definition the concept of extraordinary crime. Particularly, research raises new points of view for law students regarding the interpretation the concept of extraordinary crime in relation to criminal policy in Indonesian legal system.

\section{METHODS}

The research uses normative law research, a process to discover regulations, legal principles, and legal doctrines to react to actual legal issues (Marzuki, 2010). The method is selected to describe and analyze authentic problems related to the concepts of extraordinary crime using criminal law principles and doctrines.

Normative law research only uses secondary data from the literature study that is used. Three types of legal materials are utilized. First is primary legal material in terms of laws and regulations such as Law No. 26 Year 2000, Law No. 30 Year 2002, Law No. 6 Year 2006 and Regulation in Lieu of Law No. 1 Year 2016. Succeeding is secondary legal material in terms of books, journals and, outcomes from previous researches that clarify the primary legal materials. The last is tertiary law materials such as Internet resources that clarify the primary and secondary legal materials, including constitutional court verdicts. Research begins with manual and electronic searching through regulations, books, journals, previous research related to the concept of extraordinary crime. All collected data are then selected, processed, and analyzed using the concept of criminal policy to produce conclusions.

\section{RESULTS AND DISCUSSIONS}

The international community has reached consensus regarding the limitation of categorization of the most serious crime. When Rome Statute 1998 signed, only genocide, crimes against humanity, war crimes, and the crime of aggression that meet the threshold of the most serious crime (Jha, 2014). During the drafting of Rome Statute, the global community is debating whether terrorism and drug abuse offenses meet the threshold of the most extraordinary crime but then the international community fails to reach a consensus and both crimes rejected as the most serious crime.

As the additional explanation of categorization of the most serious of the crime, Mark A Drumble has given his definition of the concept of the most serious crime. According to Drumble 
(2007), the very core of the most serious crime is conduct - planned, systematized, and organized that targets large numbers of individuals based on their actual or perceived membership in a particular group that has become selected as a target on discriminatory grounds. From the definition, the most serious of the crime shall see in two related aspects, crime, and victim. First, the crime shall be held with the plan, systematic, and organize. Second, the victim shall be huge for some selected groups. Both aspects shall be fulfilled to meet the threshold of the most serious crimes.

No legal definition of the concept of extraordinary crime in legislations or Constitutional Court verdicts. The definitions are provided by scholars based on types of the extraordinary crime. Using gross violation of human right as references, Muladi has defined the concept of extraordinary crime as the crime that in criminology and victimology perfectives potentially to harm the interests of various dimensions, from the security order, systematic or organized, threatening political stability, future development, and others (Siswadi, 2015). Then, as reported by Hamid (2015), in accordance with corruption Romli Atmasasmita in $22^{\text {th }}$ Seminar Attorney Association in North Sumatra University 6 June 2015 has defined the concept of extraordinary crime from legal impact perfective as the massive and systemic crime. From both definitions, the concept of the extraordinary crime shall fulfill two elements, crime and impact. The crime shall be held with systematically and the impact shall be massive.

Historically, the concept of extraordinary crime is adapted from the concept of most serious crime in Rome Statute. Law No. 26 Year 2000 is the first time legislation that uses this concept. Historically, it is begun when a gross violation of human right had happened after the East Timor referendum in 1999. Some principles adopt from Rome Statute and adjust with Indonesian Legal System including the concept of the most serious of the crime. The concept is presented and recognized with new concepts known as the extraordinary crime. In such law, the gross violation of human right, which covers genocide and crime against humanity that defines as an extraordinary crime. Both crime definitions are same with the definition in Article 6 and 7 Rome Statute (Muladi, 2011). The concept of extraordinary crime, for gross violation of the human right, is in accordant with Drumble's definition of the concept of most serious crime. Therefore, categorization of gross violation of human right as extraordinary crime does meet the threshold of the most serious of crime but with limited types of crime.

Inconsistently, categorization for other types of the extraordinary crime does not use the threshold of the most serious of the crime as guidelines. Not all those crimes conducted with systematically and the impact shall be massive. However, the concept of extraordinary crime is introduced for terrorism, corruption, drug abuse offenses, and child sexual abuse offenses because of several reasons.

First, state emergency purpose, in this case is applied for terrorism. When the bombing of Bali I terrorist attack happened in 2002, Indonesia did not have anti-terrorism legislation. The impact of this terrorist attack was massive and became an international concern. For investigation, prosecution and court trial purpose for the perpetrators, Regulation in Lieu of Law No. 1 Year 2002 was issued. Important to declare that terrorism as an extraordinary crime because consequences of the crime are violating basic human rights, disrupt the economic system, spoil the state's integrity, claim victims of innocent civilians, and damage public facilities that very significant. And the perpetrators can be categorized as political offenders with a political purpose to be achieved by violence. These acts are intended to shock or intimidate the government yet victimize the innocent public and create a social impact by way of violence or violent threats, thus arousing fear (Dayan \& Selvaratnam, 2014). Therefore the concept of extraordinary crime is introduced for terrorism through Law No. 6 Year 2006. In General explanation, it states that terrorism is an extraordinary crime and a gross violation of human right especially right to live. 
Second, the development of corruption becomes more systemic, and its impact becomes more massive. Indonesia already had issued an anti-corruption law in 1971, but the concept of extraordinary crime lately introduced for corruption in 2002. In general explanation of anti-corruption law has stated that corruption has become more methodical and systematic, so it is a breach of social and economic rights of society. Supreme Court Judge, Alkostar (2013) has added that corruption in Indonesia has become systemic because already infiltrate into executive, legislative, and judicature systems in Indonesia. And it also accrues in all across Indonesia. Since corruption has more systemic, epidemic, ingrained, and flagrant that causes economic and mental loss (Muladi, 2006), thus declaring corruption as extraordinary crime is a key for corruption eradication.

Next ratification of international conventions declares that crime as serious crime. Constitutional Court has defined drug abuse offenses as the serious crime because international conventions said that matters. Indonesia has ratified the United Nation Convention Single Convention on Narcotic Drugs, 1961, and the United Nations Convention against Illicit Traffic in Narcotic Drugs and Psychotropic Substances, 1988, which both conventions clarified drug offenses as serious crimes. In addition drug abuse offences are grave and serious crime, but only drug offences with aggravating factors may elevate it to the serious offences which proscribe a wide range of activities related to the production, cultivation, trafficking, transportation, possession or purchase of illegal narcotics, as well as other offences related to laundering of proceeds from the drug trade. The crimes should be considered as the particularly serious crime if involving the participation with the domestic or international group, using the violation or firearms, and involvement of minor and the collaboration of public official (Lines, 2010). Then, in the constitutional court hearing process executive has argued that drug offenses are the extraordinary crime because it aims at killing and destroying human beings slowly but surely (Lynch, 2009). Thus the Constitutional Court through verdicts No. 2/PUU-V/2007 and No. 3/PUU-V/2007 dated October, $30^{\text {th }}$, 2007 implemented the concept of extraordinary crime for drug abuse offenses.

Then, child sexual abuse offenses have declared as the extraordinary crime because it is a sensitive crime that attracts public attention. President Joko Widodo has stated that child sexual abuse offenses as an extraordinary crime and then issued the Regulation in Lieu of Law No. 1 Year 2016. As mention in general explanation, the regulation is issued because of the increasing from time to time and significantly threaten and endanger the lives of children, damaging private life and child development, as well as disrupt the sense of comfort, tranquility, security, and public order. According to the explanation, child sexual abuse offenses consider as a sensitive crime because two aspects, the victim, and its impact. Child as the victim is weak and vulnerable to a crime that has no power and needs adults to conduct and fulfill its rights. Subsequently, indeed the impacts of child sexual abuse cases are expected to be very wide. It is a sensitive issue due to the child as the victim is considered as a vulnerable group. United Nation Convention on Child Right 1988 reaffirmed has stated that child, because of his physical and mental immaturity, needs special safeguards and care including appropriate legal protection, before as well as after birth. Then, child sexual abuse generates great anguish and destruction in the lives of these children. It is a violation of the child's physical and psychological integrity and a transgression of the moral norms of the child and society. Thus, child sexual abuse is a violation of human rights (Simuforosa et al., 2014). Consequently, child sexual abuse offenses case becomes sensitive issues that attract public attention and empathy.

The development of categorization of the concept extraordinary crime deliberates cons. Disagreement is because characteristics of the crimes do not meet the definition of the most serious of the crime. In fact, international law also has rejected those crimes as the most serious crime because of several factors. Historically, international communities itself have rejected the proposal to categorize terrorism as the most serious crimes. The rejection is based several arguments such as lack of a clear and universally accepted definition of terrorism. Terrorism does not rise to this level of international concern that consists of treaty crime which there is already in place a system of the international corporation to deal with it. And terrorism is such a politically-sensitive term, and if it is accepted, it 
will be forced into the political realm and thus will hurt its legitimacy and credibility as an impartial judicial institution (Cohen, 2012). Thus terrorism does not comply with the threshold of the most serious crime in Rome Statute.

Alike as terrorism, during the drafting process of Rome Statute, drug offenses failed to meet the requirements as the most serious crimes concern to the international community. The failure of international community to support the inclusion of drug offenses as the most serious crimes concern to the international community. As mention in Rome Statute is the indication of lack of consensus on the definition of drug offenses which neither present a threat to world peace nor do the shock the conscience of the world community (Lines, 2010). Although drug abuse offences could be considered as serious crime if the crime conducting with aggravating factors as describe in Article 3 United Nations Convention Against Illicit Traffic in Narcotic Drugs and Psychotropic Substances, 1988. This serious crime shall not be interpreted same with the most serious crime as mention in Rome Statute.

None of the international conventions state corruption as the extraordinary crime or the most serious of the crime. Indonesia has ratified some international convention regarding anti-corruption including the United Nation Convention against Corruption. Rome Statute and United Nation on Trans-National Organized Crime, none of these conventions declare corruption as the extraordinary crime or the most serious of the crime.

In international law, child sexual abuse offenses shall be regarded as the most serious crime if it conducts with the aggravating factor. It is regulated among other things by the Rome Statute; the aggravating factor is child sexual abuse offenses against children in situations of armed conflict such as rape and other grave sexual abuse of children. This does not comply with a condition in Indonesia.

The concept of extraordinary crime is parts of the criminal policy, but it is without standard categorization. The criminal policy is a crime eradication effort through criminal legislation drafting for social welfare protection purposes (Arif, 2008). As part of the criminal policy, a state has authority to select which crime that should be determined as the extraordinary crime. Selecting crimes are built on politics, legal and social interest priority from the state. Unfortunately, Indonesia does not have a standard categorization for this concept, and it will influence the entire process of criminal policy. A standard categorization shall be necessary for extending the effectiveness of the criminal policy.

The implantation of the concept of the extraordinary crime shall affect the formulating process of penal policy. An excellent criminal legislation is required in order to eradicate the extraordinary crime and it is not only formulating of criminalization. The crime should be considered as the criminal offense and sentencing elements that should be implemented for the perpetrator. But more than that, it requires formulating other penal efforts including administration of criminal justice in narrow sense, criminal jurisprudence, criminal process in wide sense, criminal process in wide sense, forensic psychiatry and psychology (Arif, 2008). Therefore in the concept, an extraordinary crime requires extraordinary efforts as a strategy for eradicating the extraordinary crime. The penal policy strategy is reflected in criminal legislations. At least, there are five penalty efforts as consequences of the implementation of the concept of extraordinary crime in legislations.

First, the retroactive principle is the exception of legality principle and applies in an extraordinary situation. This principle is the exception of the legality principle in Article 1 paragraph 1 Indonesian Penal Code, which stated that no act should be punishable by virtue of prior statutory penal provision (Hiariej, 2014). Indonesia has implemented this principle twice. First is in Law No. 26 Year 2000. Article 43 has stated that for gross violation of human right occurring prior the coming into force of the legislation should be trialed by the ad hoc human right court. This provision is regulated for the purpose of law enforcement for East Timor gross violation of human right perpetrators. Thus the perpetrators could be the trial under national legislation. Second is when Executive passed Regulation in Lieu of Law No. 1 Year 2002 as a response to bomb Bali 1 terrorist attack. 
Succeeding is the implementation of capital punishment, which is considered as the heaviest punishment. Article 6 paragraph 2 International Convention of Civil and Politic Rights (ICCPR) has stated that in countries which have not abolished the death penalty, sentence of death may be levied only for the most serious crimes. Indonesia has ratification ICCPR in 2005, subsequently Indonesia has the right to apply capital punishment for crimes that think as serious crimes. Executive and Legislative interpret words 'serious crimes' in Article 6 paragraph 2 ICCPR as the extraordinary crime. Thus capital punishment applies to legislations for extraordinary crimes including for gross violation of human right, corruption, terrorism, and drug abuse offenses. So do the Panel of Judges of the Constitutional Court who has legalized of capital punishment in the Indonesian legal system as mention in No. 2/PUU-V/2007 and No. 3/PUU-V/2007. However, capital punishment does not exclusive apply for extraordinary crimes, in fact, capital punishment also imposes for fresh crimes in the Indonesian Penal Code, such as homicide, treason robbery with violating which coursing death and hijacking.

Next is the implementation of a measure (maatregelen). It is a treatment that given to a perpetrator as a substitute for the punishment. The only qualified perpetrator can be treated. As mention in Article 44 Indonesia Penal Code, a person who commits an act for which because of the defective development or sickly disorder of his mental capacities shall not be punished. However, Judge can order the perpetrator is placed in a lunatic asylum during a probation time not exceeding the term of one year for examination. Similarly with measure (maatregelen) concept in Law No. 11 Year 2012, measure (maatregelen) is imposed for an under 14 years old when criminal offense conducted. Types of measure (maatregelen) in this law are return to the parent/guardian, surrender to someone, treatment in a mental hospital, treatment in Institutions of Social Welfare, obligation to enroll the formal education and/or training organized by the government or private entity, revocation of a driver's license, and/or repair of criminal offenses.

The development of a measure (maatregelen) becomes contradiction, especially after chemical castration mention as the measure (maatregelen) as regulated in Regulation in Lieu of Law No. 1 Year 2016. Chemical castration thinks as torture and cruel punishment also against with criminal law principles. An Obstetrician, Boyke Dian Nugraha, and an Andrologist Wimpie Pangkahila chemical castration are torture and crueler than death penalty because delivers negative effects on perpetrator's body and health event can cause death as reported (Prawira, 2016). This is in contradiction to Article 7 ICCPR and Convention against Torture and other Cruel, Inhuman or Degrading Measure or Punishment, which have signed by Indonesia. Both conventions prohibit types of torture, cruel, inhuman or degrading measure or punishment. Then Article 81A paragraph (7) the Regulation in Lieu of Law No. 1 Year 2016 regulates that chemical castration shall be executed a maximum two years after the conviction completes his/her punishment. It is contradictory with rehabilitation purpose of a sentencing, a convict who complete his/her punishment and has healed, he/she can be reintegrated into society, therefore, he/she shall not be punished again with chemical castration.

Other is special independent or non-independent commission, and board is established as part of the criminal justice system. Reksodiputro (2007) has argued that law enforcement is part of the criminal justice system, an integrative system for crime eradication purpose, thus for extraordinary crime, an extraordinary system requires to prevent and surmount that crime. Then special institutions shall be established. One of those institutions is the Corruption Eradication Commission (KPK/Komisi Pemberantasan Korupsi) with the purpose for the prevention and eradication corruption act. As an impartial commission under President supervision, KPK duties are to supervise the implementation of corruption eradication, conducting the investigation and prosecution process for actual corruption cases, and conducting corruption prevention. Additional institutions are National Counter-Terrorism Board (BNPT/Badan Nasional Penanggulangan Terorisme) and National Narcotics Board (BNN/Badan Narkotika Nasional). Unlike KPK, both are special boards in Indonesia police under the supervision of the Indonesian Police Chief, which has a function in the investigation process. 
Last is the exceptional court established for deliberate the better trial process. Indonesia establishes Human Right Court for the perpetrator of gross violation of human rights. Other courts are Corruption at court, establishes through Law No. 46 Year 2009. This superior court has jurisdiction to try Corruption Act cases, which are investigated and prosecuted by KPK. Both courts are under Supreme Court supervision. Give better judgment, the panel of judges of this court consists of a carrier and ad hoc judges. However, not all special courts are established as results of the implementation of concept extraordinary crime. Special courts might establish because two causes. First, characteristic of the crime itself such as illegal fishing court which has exclusive jurisdiction. Second because of the subjectivity of the perpetrator, such as juvenile court.

Determination of penalty efforts as consequences of the implementation of the concept of the extraordinary crime shall be in accordance with a strategy of crime eradication and welfare protection purposes. No standard or mandatory penalty efforts as consequences of implementation of the concept of extraordinary crime. Yet, the penalty effort shall be in line with criminal law principles and human true basic principles to extend the effectiveness of the criminal policy.

The effectiveness of implementation of the concept extraordinary crime requires more than criminalization and sentencing. Lack of standard of categorization in the concept extraordinary crime may affect the criminalization and sentencing process. The concept of extraordinary crime in child sexual abuse offenses is the example. The difference with other types of extraordinary crimes, child sexual abuse offenses do not meet two elements, which shall be conducted with systematically and the impact shall be massive. It impacts the strategy for eradication of child sexual abuse offenses in penal efforts. Subsequently, when executive issued the Regulation in Lieu of Law No. 1 Year 2016 with delivering a lot of debates. The additional is the provision regarded the aggravating for criminal offences (gequalificeerde delict) and sentencing with the heaviest sentences covering the death penalty, life imprisonment and a maximum term of imprisonment of twenty years and a minimum term of imprisonment for five years, as well as a maximum fine of the amount of five billion Rupiah. Then, it is also introduced new types of sentencing such as publication of the perpetrator's identity as additional sentence and chemical castration and mounting chip for the perpetrator as measures (maatregelen). Lammdari has argued that penal policy for child sexual abuse requires more than the heavy penalty, but the most important require prosecution patterns that provide protection and glorification senses for child sexual abuse victim (Eddyono et al., 2016). The in regulation is only regulated regarding the aggregative sentencing without any penalty efforts regarding prevention and treatment mechanism for the victim. Therefore issuance of the regulation is considered as firefighter policy, but it does not solve the real problems.

\section{CONCLUSIONS}

Based on the analysis, the conclusions of this research are as follows. Is the inconsistency of categorization of the concept of extraordinary crime affecting the threshold of the concept of extraordinary crime? The concept is adopted from the concept of the most serious crime in Rome Statute and adjusted with politic, legal and social interest priority from a state. The threshold of the concept of extraordinary crime categorization is not strictly based on the categorization of the most serious of crime but other reasons such as urgency, the development of crimes, ratification of international conventions and public interest. The concept of extraordinary crime does not have standard categorization to accommodate priority of state's criminal policy. However, it gives impacts to the effectiveness of the criminal policy.

Then, there is no standard or mandatory penalty effort as consequences of implementation of the concept of extraordinary crime. Determination of penalty efforts as consequences of the 
implementation of the concept of the extraordinary crime shall be in accordance with the strategy of crime eradication and welfare protection purposes. However, because of lack of categorization of the concept of extraordinary crime, it gives impacts to the effectiveness of the criminal policy.

\section{REFERENCES}

Alkostar, A. (2013). Korupsi Sebagai Extra Ordinary Crime. (Paper from Training Mainstreaming Human Rights Approaches In Combating Corruption In Indonesia Judge For All Indonesia). Retrieved from e-pushamuii.org/files.php?type=pdf\&id=292.

Arif, B. N. (2008). Bunga Rampai Kebijakan Hukum Pidana Perkembangan Penyusunan Konsep KUHP Baru. Jakarta, Indonesia: Kencana.

Cohen, A. (2012). Prosecuting Terrorists at the International Criminal Court: Reevaluating an Unused Legal Tool to Combat Terrorism. Michigan State International Law Review, 20 (2), 220-260.

Dayan, M. R. \& Selvaratnam, D. P. (2014). Anti-Criminalization System for Perpetrators of Criminal Acts of Terrorism. Journal Of Humanities And Social Science. 19 (6), 30-32.

Drumble, M. A. (2007). Atrocity, Punishment and International Law. New York: Cambrige University Press.

Eddyono, S. W., Sofian, A., Akbari, A. R. (2016). Menguji Euforia Kebiri Catatan Kritisatas Kebijakan Kebiri (Chemical Castration) Bagi Pelaku Kejahatan Sexual di Indonesia. Jakarta, Indonesia: Aliansi 99 Tolak Kebiri.

Hamid, A. A. (2015, $6^{\text {th }}$ June). Praktisi: Tindak Pidana Korupsi di Indonesia Sebagai Kejahatan Luar Biasa. Retrieved $20^{\text {th }}$ July 2016 from http://www.aktual.com/praktisi-tindak-pidana-korupsidi-indonesia-sebagai-kejahatan-luar-biasa/

Hiariej, E. O.S. (2014). Prinsip-Prinsip Hukum Pidana. Yogyakarta: Atma Pustaka.

Jha, U.C. (2014). Armed Conflict and Environmental Demage. New Delhi, India: Vij Book India Pvt Ltd.

Lines, R. (2010). A 'Most Serious Crime?' - The Death Penalty for Drug Offences and International Human Rights Law. Amicus Journal, 12, 21-28.

Lynch, C. (2009). Indonesia's Use Of Capital Punishment For Drug-Trafficking Crimes: Legal Obligations, Extralegal Factors, And The Bali Nine Case. Colombia Human Right Review, 3 (5), 523-592.

Marzuki, P. M. (2010). Penelitian Hukum. Jakarta: Kencana.

Muladi.(2011). Statuta Roma Tahun 1998 tentang Mahkamah Pidana Internasional Dalam Kerangka Hukum Pidana Internasional dan Implikasinya terhadap Hukum Pidana Nasional. Bandung: Alumni. 
Muladi. (2006, $8^{\text {th }}$ November). Konsep Total Enforcement dalam Pemberantasan Tindak Pidana Korupsi dalam Kerangka Politik Hukum. Paper presented at Eradication Corruption Coordination and Consulation forum.

Prawira, A. E. (2016, 28 ${ }^{\text {th }}$ May). Dampak Kebiri Kimiawi, Laki-laki Berubah Seperti Perempuan. Retrieved August $16^{\text {th }} 2016$ from http://health.liputan6.com/read/2518099/dampak-kebirikimiawi-laki-laki-berubah-seperti-perempuan.

Reksodiputro, M. (2007). Sistem Peradilan Pidana Indonesia (Melihat kepada Kejahatan dan Penegakan Hukum dalam Batas-Batas Toleransi). Universitas Indonesia: Pidato Pengukuhan.

Sekretariat Negara RI. (2000). Undang-Undang No. 26 tentang Pengadilan Hak Asasi Manusia. Lembaran Negara RI Tahun 2000, No 208. Sekretariat Negara. Jakarta.

Sekretariat Negara RI. (2002). Peraturan Pemerintah Pengganti Undang-Undang No. 1 tentang Pemberantasan Tindak Pidana Terorisme. Lembaran Negara RI Tahun 2002, No. 106. Sekretariat Negara. Jakarta.

Sekretariat Negara RI. (2002). Undang-Undang No. 30 tentang Komisi Pemberantasan Korupsi. Lembaran Negara RI Tahun 2003, No 137. Sekretariat Negara. Jakarta.

Sekretariat Negara RI. (2006). Undang-Undang No. 6 tentang Pengesahan International Convention For The Suppression of The Financing Of Terrorism, 1999 (Konvensi Internasional Pemberantasan Pendanaan Terorisme, 1999). Lembaran Negara RI Tahun 2006, No. 29. Sekretariat Negara. Jakarta.

Sekretariat Negara RI. (2009). Undang-Undang No. 46 tentang Pengadilan Tindak Pidana Korupsi. Lembaran Negara RI Tahun 2009 No. 155. Sekretariat Negara. Jakarta.

Sekretariat Negara RI. (2012). Undang-Undang No. 11 tentang Sistem Peradilan Anak. Lembaran Negara RI Tahun 2012 No. 153. Sekretariat Negara. Jakarta.

Sekretariat Negara RI. (2016). Peraturan Pemerintah Pengganti Undang-Undang No. 1 tentang Perubahan Kedua Atas Undang-Undang No. 23 Tahun 2002 Tentang Perlindungan Anak. Lembaran Negara RI Tahun 2016, No. 99. Sekretariat Negara. Jakarta.

Simuforosa, M., \& Viola, I. (2014). Exploring Sexual Abuse of School Children in Families: A Case Study of Masvingo District, Zimbabwe. The International Journal Of Humanities \& Social Studies, 2 (9), 156-161.

Siswadi, D. (2015). The Legal Framework of Human Right Crime as an Extraordinary Crime. International Journal of Scientific and Technology Research, 4 (8), 216-218. 